\title{
Adsorption Characteristics of Different Adsorbents and Iron(III) Salt for Removing As(V) from Water
}

\author{
Josip Ćurko, Marin Matošić, Vlado Crnek, Višnja Stulić and Ivan Mijatović* \\ Faculty of Food Technology and Biotechnology, University of Zagreb, Pierottijeva 6,
} HR-10000 Zagreb, Croatia

Received: January 13, 2015

Accepted: December 9, 2015

\begin{abstract}
Summary
The aim of this study is to determine the adsorption performance of three types of adsorbents for removal of $\mathrm{As}(\mathrm{V})$ from water: Bayoxide ${ }^{\circledR}$ E33 (granular iron(III) oxide), Titansorb $^{\circledR}$ (granular titanium oxide) and a suspension of precipitated iron(III) hydroxide. Results of $\mathrm{As}(\mathrm{V})$ adsorption stoichiometry of two commercial adsorbents and precipitated iron(III) hydroxide in tap and demineralized water were fitted to Freundlich and Langmuir adsorption isotherm equations, from which adsorption constants and adsorption capacity were calculated. The separation factor $R_{\mathrm{L}}$ for the three adsorbents ranged from 0.04 to 0.61 , indicating effective adsorption. Precipitated iron(III) hydroxide had the greatest, while Titansorb had the lowest capacity to adsorb As(V). Comparison of adsorption from tap or demineralized water showed that Bayoxide and precipitated iron(III) hydroxide had higher adsorption capacity in demineralized water, whereas Titansorb showed a slightly higher capacity in tap water. These results provide mechanistic insights into how commonly used adsorbents remove $\mathrm{As}(\mathrm{V})$ from water.
\end{abstract}

Key words: arsenic removal, drinking water, adsorption

\section{Introduction}

The prevalence of toxic arsenic in drinking water is a significant worldwide problem. Most developed countries have implemented strict regulations based on World Health Organization guidelines that allow no more than $10 \mu \mathrm{g} / \mathrm{L}$ of arsenic in drinking water (1). However, many developing countries do not have the infrastructure or water resources to implement or enforce such a policy, leading to a recommendation that they initially implement a maximum contaminant level of $50 \mu \mathrm{g} / \mathrm{L}$ of As to provide at least some protection against higher As concentrations (2). For all countries, affordable and efficient arsenic removal systems are crucial for creating and maintaining a safe drinking water supply.

Arsenic can be present in water in an oxidation state of $-3,0,+3$ or +5 , depending on the $\mathrm{pH}$ and redox potential of the water. It occurs in water most often as trivalent arsenite $\left(\mathrm{H}_{3} \mathrm{AsO}_{3}, \mathrm{H}_{2} \mathrm{AsO}_{3}{ }^{-}, \mathrm{HAsO}_{3}{ }^{2-}\right.$ and $\left.\mathrm{AsO}_{3}{ }^{3-}\right)$ and pentavalent arsenate $\left(\mathrm{H}_{3} \mathrm{AsO}_{4}, \mathrm{H}_{2} \mathrm{AsO}_{4}^{-}, \mathrm{HAsO}_{4}{ }^{2-}\right.$ and $\left.\mathrm{AsO}_{4}{ }^{3-}\right)$. Arsenite, or $\mathrm{As}(\mathrm{III})$, is usually present as an uncharged molecule $\left(\mathrm{H}_{3} \mathrm{AsO}_{3}\right)$ in the water with low redox potential and a $\mathrm{pH}$ between 6.5 and 9.2, while pentavalent arsenate, or As $(\mathrm{V})$, is usually present as a negatively charged molecule $\left(\mathrm{H}_{2} \mathrm{AsO}_{4}^{-}\right)$in the water of the same $\mathrm{pH}$ range but with a more oxidized aerobic environment (3).

The oxidation state of arsenic determines whether it can be efficiently removed from drinking water by standard methods, which usually include a multistep process involving oxidation followed by adsorption or separation (4). For example, because arsenite can be uncharged, it is harder to remove it from water than negatively charged arsenate (5). Oxidation can be used to convert arsenic into an oxidation state favourable for removal, followed usually by either adsorption or separation. Separation usually involves filtering the contaminated water and separat- 
ing arsenite and arsenate from the water by membrane-based processes such as reverse osmosis or nanofiltration (6).

Adsorption, an alternative method to separation, may involve various types of natural or synthetic adsorbents (4), including precipitated iron or aluminium hydroxides, ion exchangers, metal oxides such as iron, manganese and titanium, laterites, zeolites, activated charcoal and natural red earth (7-13). In cases when water is not heavily contaminated with arsenic and no oxidation or $\mathrm{pH}$ correction is necessary, commercially available granular iron(III) hydroxide and oxide are widely used because they have high adsorption capacity $(11,14)$ and can be disposed of safely. The adsorbent titanium dioxide $\left(\mathrm{TiO}_{2}\right)$ actually plays a dual role of photocatalyst and adsorbent for arsenic removal. In the presence of artificial or natural UV light, $\mathrm{TiO}_{2}$ can photocatalyze the oxidation of $\mathrm{As}(\mathrm{III})$ to $\mathrm{As}(\mathrm{V})$, which then adsorbs onto the $\mathrm{TiO}_{2}$ surface. In the absence of $\mathrm{UV}$ radiation, $\mathrm{TiO}_{2}$ acts only as an adsorbent and shows adsorption capacity and adsorption kinetics superior to those of iron-based adsorption media. Pena at al. (15) showed granular $\mathrm{TiO}_{2}$ to have higher adsorption capacity than similarly sized granular iron(III) oxide.

One of the most common methods currently used to remove arsenic from drinking water is adsorption on precipitated hydroxides used for coagulation of colloidal particles with iron or aluminium salts. Coagulation is usually used in water treatment to remove turbidity and suspended solids, but hydroxides that form from coagulant salts can bind $\mathrm{As}(\mathrm{V})$ by either incorporating it into the hydroxide matrix or by adsorbing it electrostatically onto the positively charged hydroxide surface (16). This method in combination with sand filtration as a final step in the process sometimes does not remove arsenic to meet the maximum contaminant level of $10 \mu \mathrm{g} / \mathrm{L}$ in the treated water. This is primarily due to the inefficiency of sand filtration, which does not successfully remove particles smaller than $10 \mu \mathrm{m}$ on which adsorbed $\mathrm{As}(\mathrm{V})$ can be located (17).

Researchers continue to search for more efficient methods to adsorb arsenic from water, which has led to a broad range of adsorbents (4). Though the efficiency of these adsorbents can vary depending on physical factors that influence the complex chemistry of arsenic in water, relatively few studies have compared the functional characteristics of several types of adsorbents $(7,11,18,19)$. In particular, little is known about the comparative functional characteristics of iron coagulant and adsorbents based on iron(III) oxide or titanium oxide.

To provide some of these data and thereby create a basis for improving arsenic adsorption methods, we investigated and compared the removal of $\mathrm{As}(\mathrm{V})$ from model solutions using commercial adsorptive media Bayoxide $^{\circledR}$ E33 (granular iron(III) oxide), Titansorb ${ }^{\circledR}$ (granular titanium dioxide) and iron(III) chloride as a precipitated suspension of iron(III) hydroxide. Results of $\mathrm{As}(\mathrm{V})$ adsorption stoichiometry on the three used adsorbents in tap and demineralized water were fitted to Freundlich and Langmuir isotherm models to gain insights into the adsorption mechanism.

\section{Material and Methods}

\section{Water samples}

Three types of adsorbents were investigated for the removal of $\mathrm{As}(\mathrm{V})$ from tap and demineralized water spiked with $\mathrm{As}(\mathrm{V})$. The characteristics of the water used in this study are shown in Table $1 . \mathrm{AsHNa}_{2} \mathrm{O}_{4} \cdot 7 \mathrm{H}_{2} \mathrm{O}$ (Fluka Chemie $\mathrm{GmbH}$, Buchs, Switzerland) was used to prepare solutions of tap or demineralized water containing the following concentrations of $\mathrm{As}(\mathrm{V}): 100,200,300,400$, 500 and $600 \mu \mathrm{g} / \mathrm{L}$.

Table 1. Characteristics of tap and demineralized water

\begin{tabular}{|c|c|c|}
\hline Parameter & $\begin{array}{c}\text { Tap } \\
\text { water }\end{array}$ & $\begin{array}{c}\text { Demineralized } \\
\text { water }\end{array}$ \\
\hline$\overline{\mathrm{pH}}$ & 7.2 & 7 \\
\hline$\gamma($ suspended matter $) /(\mathrm{mg} / \mathrm{L})$ & 0 & 0 \\
\hline Electrical conductivity $/(\mu \mathrm{S} / \mathrm{cm})$ & 680 & $<0.1$ \\
\hline Total hardness $/\left(\mathrm{mg} \mathrm{CaCO}_{3} / \mathrm{L}\right)$ & 375 & 0 \\
\hline Alkalinity $/\left(\mathrm{mg} \mathrm{CaCO}_{3} / \mathrm{L}\right)$ & 340 & 0 \\
\hline$\gamma(\mathrm{As}) /(\mu \mathrm{g} / \mathrm{L})$ & $<1$ & 0 \\
\hline$\gamma(\mathrm{Fe}) /(\mu \mathrm{g} / \mathrm{L})$ & 0.2 & 0 \\
\hline$\gamma(\mathrm{Mn}) /(\mu \mathrm{g} / \mathrm{L})$ & 0.2 & 0 \\
\hline$\gamma\left(\mathrm{Cl}^{-}\right) /(\mathrm{mg} / \mathrm{L})$ & 15 & 0 \\
\hline$\gamma\left(\mathrm{SO}_{4}^{2-}\right) /(\mathrm{mg} / \mathrm{L})$ & 27 & 0 \\
\hline$\gamma\left(\mathrm{PO}_{4}{ }^{3-}\right) /(\mathrm{mg} / / \mathrm{L})$ & $<0.01$ & 0 \\
\hline
\end{tabular}

\section{Adsorbents}

The following three types of adsorbents were studied: Bayoxide ${ }^{\circledR}$ E33, Titansorb ${ }^{\circledR}$ and precipitated suspension of iron(III) hydroxide. Bayoxide ${ }^{\circledR}$ E33 is granulated iron(III) oxide medium developed by LANXESS GmbH, Leverkusen, Germany. Manufacturer's specifications are as follows: $>70 \%$ content of $\mathrm{Fe}_{2} \mathrm{O}_{3}$, bulk density of 0.6 $\mathrm{kg} / \mathrm{L}$, grain size of $0.5-2.0 \mathrm{~mm}$ and specific surface area of at least $250 \mathrm{~m}^{2} / \mathrm{g}$. Titansorb ${ }^{\circledR}$ is granulated titanium dioxide developed by Watch GmbH, Mannheim, Germany. Manufacturer's specifications are as follows: grain size of $0.5-1.5 \mathrm{~mm}$, bulk density of $0.6 \mathrm{~kg} / \mathrm{L}$ and specific surface area of $350-450 \mathrm{~m}^{2} / \mathrm{kg}$. Precipitated iron(III) hydroxide was prepared by adding $\mathrm{FeCl}_{3}$ (Sigma-Aldrich, Saint Louis, MO, USA) to model solutions to achieve desired concentrations of precipitated hydroxide, which were then expressed as Fe(III) in $\mathrm{mg} / \mathrm{L}$.

\section{Adsorption tests}

All adsorption experiments were conducted at a constant temperature of $(20 \pm 1){ }^{\circ} \mathrm{C}$ and $\mathrm{pH}=8 \pm 0.1$ in a Jar Tester ZR 4-6 (Zhongrun Water Co. High-Tech Industrial Park, Shenzhen, Guangdong, PR China) equipped with six 1.5-litre square acrylic beakers, each with its own mixing paddle centrally controlled. Model solutions for adsorption experiments were prepared in volumes of $1 \mathrm{~L}$. At the beginning of each experiment, $\mathrm{pH}$ was corrected by the addition of $1 \mathrm{~mol} / \mathrm{L}$ of hydrochloric acid (Sigma-Aldrich) and $1 \mathrm{~mol} / \mathrm{L}$ of sodium hydroxide (Sigma-Aldrich) to achieve desired $\mathrm{pH}$ after the addition of adsorbents. 
For testing arsenic adsorption using a precipitated suspension of iron(III) hydroxide, different amounts of $\mathrm{FeCl}_{3}$ were added to $1 \mathrm{~L}$ of model solutions of tap or demineralized water containing $100 \mu \mathrm{g} / \mathrm{L}$ of $\mathrm{As}(\mathrm{V})$ to give final $\mathrm{Fe}(\mathrm{III})$ concentrations of $0.68,1.37,2.06,2.75,3.44$ and $4.12 \mathrm{mg} / \mathrm{L}$. Then, a corresponding volume of $\mathrm{FeCl}_{3}$ stock solution was added to achieve $3.44 \mathrm{mg}$ of $\mathrm{Fe}(\mathrm{III})$ in the model solutions containing $\mathrm{As}(\mathrm{V})$ concentrations of $100,200,300,400,500$ or $600 \mu \mathrm{g} / \mathrm{L}$. The iron(III) hydroxide suspension was mixed with paddles rotating at $200 \mathrm{rpm}$ for $1 \mathrm{~min}$ and then at $20 \mathrm{rpm}$ for $24 \mathrm{~h}$.

For testing arsenic adsorption by Bayoxide E33 and Titansorb, these adsorbents $(0.25 \mathrm{~g})$ were added to $1 \mathrm{~L}$ of model solutions of tap or demineralized water containing As(V) concentrations of 100, 200, 300, 400, 500 or $600 \mu \mathrm{g} / \mathrm{L}$. Solutions were mixed with paddles rotating at $150 \mathrm{rpm}$ for $24 \mathrm{~h}$.

After adsorption experiments, model solutions were filtered through a $0.45-\mu \mathrm{m}$ filter (Whatman, GE Healthcare, Dassel, Germany), and $10 \mathrm{~mL}$ of concentrated $\mathrm{HNO}_{3}$ (Fluka Chemie $\mathrm{GmbH}$ ) were added to $1 \mathrm{~L}$ of each sample in order to preserve them until later analysis by inductively coupled plasma optical emission spectrometry (ICP-OES).

\section{Adsorption column tests}

Bayoxide E33 and Titansorb were examined in column tests. Bayoxide E33 ( $V=95 \mathrm{~mL})$, bulk density of 0.6 $\mathrm{kg} / \mathrm{L}$ and grain size of $0.5-2.0 \mathrm{~mm}$ or Titansorb $(V=95 \mathrm{~mL})$, bulk density of $0.6 \mathrm{~kg} / \mathrm{L}$ and grain size of $0.5-1.5 \mathrm{~mm}$ were placed in a glass cylinder with an 11-mm diameter, and tap water spiked with $100 \mu \mathrm{g}$ of $\mathrm{As}(\mathrm{V})$ per L was pumped through the column at $5 \mathrm{~m} / \mathrm{h}$ using a peristaltic pump (ProMinent, Heidelberg, Germany), where empty bed contact time (EBCT) was $12 \mathrm{~min}$. From the mass of the used adsorbent and from the volume of spiked water that passed through the column, adsorption capacity of adsorbent $(q)$ was calculated. Spiked water was run through the column until the concentration of $\mathrm{As}(\mathrm{V})$ in effluent exceeded $\gamma=50 \mu \mathrm{g} / \mathrm{L}$. Each day, a 100-mL sample of effluent was taken and preserved by adding $1 \mathrm{~mL}$ of concentrated $\mathrm{HNO}_{3}$ for later analysis by ICP-OES.

\section{Calculation of Freundlich and Langmuir constants}

Freundlich and Langmuir constants were calculated using MS Excel (Microsoft, Redmond, WA, USA) from the initial mass concentrations of $\mathrm{As}(\mathrm{V})\left(\gamma_{0} /(\mathrm{mg} / \mathrm{L})\right)$, measured equilibrium $\mathrm{As}(\mathrm{V})$ concentration $\left(\gamma_{\mathrm{e}} /(\mathrm{mg} / \mathrm{L})\right)$ and calculated mass of adsorbate on the adsorbent at equilibrium for Freundlich $\left(q_{\mathrm{ef}} /(\mathrm{mg} / \mathrm{g})\right)$ and for Langmuir $\left(q_{\mathrm{eL}} /(\mathrm{mg} / \mathrm{g})\right)$ isotherms (20).

Freundlich constants were calculated from the linear region of a log-log diagram (Eq. 1), and then plotted as $\log q_{\mathrm{eF}} v s . \log \gamma_{\mathrm{e}}$. This plot was used to calculate the Freundlich isotherm constant $\left(K_{\mathrm{F}} /(\mathrm{mg} / \mathrm{g}) \cdot(\mathrm{L} / \mathrm{g})^{\mathrm{n}}\right)$, adsorption intensity $(n)$ and coefficient of determination $\left(\mathrm{R}^{2}\right)$.

$$
\log q_{\mathrm{eF}}=\log K_{\mathrm{F}}+1 / n \cdot \log \gamma_{\mathrm{e}}
$$

The linear Langmuir equation (Eq. 2) was plotted as $1 / q_{\mathrm{eL}}$ vs. $1 / \gamma_{\mathrm{e}}$. The slope $\left(1 / Q_{0}\right)$ and y-intercept $\left(1 /\left(K_{\mathrm{L}} \cdot Q_{0}\right)\right)$ were used to calculate the Langmuir isotherm constant $\left(K_{\mathrm{L}} /(\mathrm{L} / \mathrm{mg})\right)$, maximum monolayer coverage capacity $\left(Q_{0} /\right.$ $(\mathrm{mg} / \mathrm{g}))$ and coefficient of determination $\left(\mathrm{R}^{2}\right)$. To determine linearity, favourability or unfavourability of Langmuir isotherms, the dimensionless constant separation factor, commonly used as separation factor $\left(R_{\mathrm{L}}\right)$, was calculated according to Eq. $3(20,21)$.

$$
\begin{gathered}
1 / q_{\mathrm{eL}}=1 / Q_{0}+1 /\left(K_{\mathrm{L}} \cdot Q_{0}\right) \cdot 1 / \gamma_{\mathrm{e}} \\
R_{\mathrm{L}}=1 /\left(1+K_{\mathrm{L}} \cdot \gamma_{0}\right)
\end{gathered}
$$

\section{ICP-OES and other analyses}

$\mathrm{As}(\mathrm{V})$ concentration in tap and demineralized water was measured using inductively coupled plasma optical emission spectrometer (Iris Intrepid II XSP; Thermo Electron, Thermo Fischer Scientific Inc., Waltham, MA, USA). Other analyses used to determine $\mathrm{pH}$, temperature, suspended matter, electrical conductivity, total hardness, alkalinity, iron, manganese, chlorides and sulphates in all samples were performed according to standard methods (22).

\section{Results and Discussion}

\section{Adsorption experiments}

The removal of $\mathrm{As}(\mathrm{V})$ from spiked tap and demineralized water by precipitated iron(III) hydroxide, Bayoxide E33 and Titansorb was compared. $\mathrm{FeCl}_{3}$ served as the source of iron(III) hydroxide, since it hydrolyzes when added to water and later precipitates as insoluble hydroxide. Based on the criteria of Cornell and Schwertmann (23), it was assumed that all $\mathrm{FeCl}_{3}$ added to the model solutions hydrolyzed and precipitated as iron(III) hydroxide because the $\mathrm{pH}$ was above 2 . Since the other two adsorbents were granular, they were added directly to the spiked solutions.

Freundlich constants in tap water were 5.85 for iron(III) hydroxide, 0.13 for Bayoxide E33 and $0.07(\mathrm{mg} / \mathrm{g}) \cdot(\mathrm{L} / \mathrm{g})^{\mathrm{n}}$ for Titansorb (Table 2), suggesting that iron(III) hydroxide had the highest adsorption capacity. The value of $1 / n$ of all three adsorbents did not differ significantly, which suggested that they all had similar adsorption intensity (Fig. 1). This is consistent with the adsorption mechanism of Edwards (16), who proposed a three-step process in which arsenate precipitation is followed by its incorporation into the growing floccules of precipitated hydroxide, and finally by bonding between negatively charged arsenate and positively charged hydroxide. Titansorb showed the highest adsorption intensity $(1 / n)$ of 0.4731 (Table 2$)$, indicating the formation of a stable complex between the adsorbent and $\mathrm{As}(\mathrm{V})$.

According to the calculated constants for Freundlich isotherms, iron(III) hydroxide and Bayoxide E33 achieved better results in demineralized compared to tap water (Table 2). Iron(III) hydroxide had a $K_{\mathrm{F}}$ of $10.30(\mathrm{mg} / \mathrm{g})$. $(\mathrm{L} / \mathrm{g})^{\mathrm{n}}$, which was 1.7-fold higher than the value in tap water. Nevertheless, when we used the calculated Freundlich constants and a $\gamma_{\mathrm{e}}(\mathrm{As}(\mathrm{V}))=5 \mu \mathrm{g} / \mathrm{L}$ in Eq. 1, we found $q_{\mathrm{eF}}$ to be 20.80 and $24.70 \mathrm{mg}$ of $\mathrm{As}(\mathrm{V})$ per $\mathrm{g}$ of $\mathrm{Fe}(\mathrm{III})$ in tap and demineralized water, respectively. This suggests a similar amount of adsorbed $\mathrm{As}(\mathrm{V})$ in the two types of wa- 
Table 2. Freundlich and Langmuir isotherm constants for $\mathrm{As}(\mathrm{V})$ removal from tap and demineralized water by three adsorbents

\begin{tabular}{|c|c|c|c|c|c|c|c|c|c|c|}
\hline & \multirow[b]{2}{*}{ Adsorbent } & \multicolumn{4}{|c|}{ Freundlich isotherm constants } & \multicolumn{5}{|c|}{ Langmuir isotherm constants } \\
\hline & & $\frac{K_{\mathrm{F}}}{(\mathrm{mg} / \mathrm{g}) \cdot(\mathrm{L} / \mathrm{g})^{\mathrm{n}}}$ & $1 / n$ & $\frac{q_{\mathrm{eF}}^{*}}{\mathrm{mg} / \mathrm{g}}$ & $\mathrm{R}^{2}$ & $\frac{Q_{0}}{\mathrm{mg} / \mathrm{g}}$ & $\frac{K_{\mathrm{L}}}{\mathrm{L} / \mathrm{mg}}$ & $R_{\mathrm{L}}$ & $\frac{q_{\mathrm{eL}}^{*}}{\mathrm{mg} / \mathrm{g}}$ & $\mathrm{R}^{2}$ \\
\hline \multirow{3}{*}{ 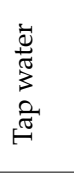 } & $\begin{array}{l}\text { Iron(III) } \\
\text { hydroxide }\end{array}$ & 5.85 & 0.7880 & 20.80 & 0.9571 & 376.2 & 10.4 & 0.49 & 18.60 & 0.9685 \\
\hline & Bayoxide E33 & 0.13 & 0.7535 & 0.42 & 0.9510 & 8.0 & 9.5 & 0.51 & 0.36 & 0.9954 \\
\hline & Titansorb & 0.07 & 0.4731 & 0.14 & 0.9458 & 1.2 & 11.6 & 0.46 & 0.06 & 0.9380 \\
\hline \multirow{3}{*}{ 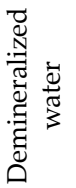 } & $\begin{array}{l}\text { Iron(III) } \\
\text { hydroxide }\end{array}$ & 10.30 & 0.5454 & 24.70 & 0.9012 & 181.9 & 23.9 & 0.29 & 24.30 & 0.9766 \\
\hline & Bayoxide E33 & 0.47 & 0.3639 & 0.85 & 0.9277 & 1.9 & 229.5 & 0.04 & 1.04 & 0.9848 \\
\hline & Titansorb & 0.05 & 0.5195 & 0.11 & 0.9114 & 1.4 & 6.5 & 0.61 & 0.04 & 0.9971 \\
\hline
\end{tabular}

${ }^{*}$ Calculated amount of adsorbate in the adsorbent at an equilibrium concentration of $\gamma_{\mathrm{e}}=5 \mu \mathrm{g} / \mathrm{L}$

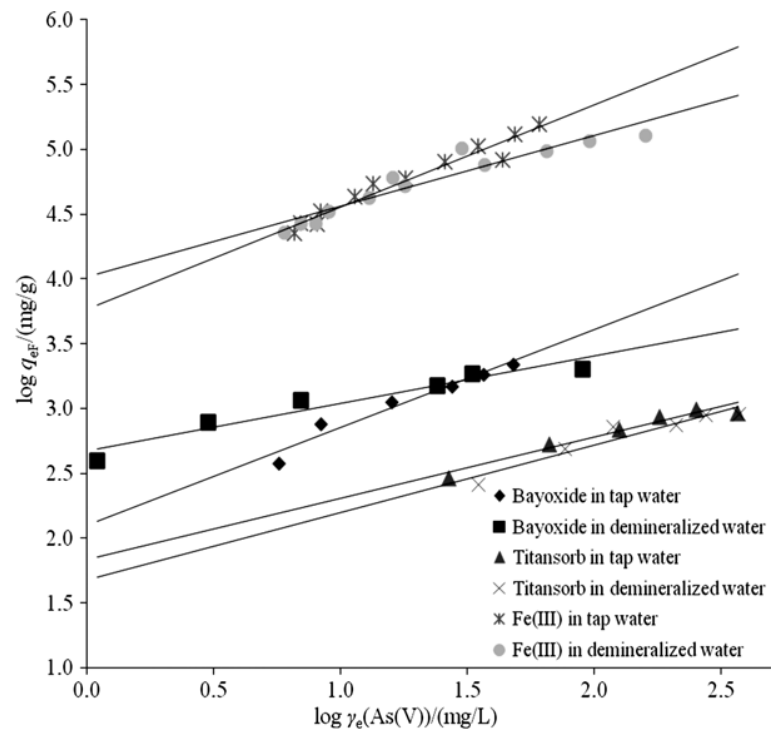

Fig. 1. Dependence of $\mathrm{As}(\mathrm{V})$ adsorbed at equilibrium $\left(q_{\mathrm{eF}}\right)$ on $\mathrm{As}(\mathrm{V})$ concentration in a solution, used to calculate Freundlich isotherm constants

ter. Mitrakas et al. (24) developed a mathematical model for prediction of $\mathrm{Fe}(\mathrm{III})$ dose for removal of $\mathrm{As}(\mathrm{V})$ at different $\mathrm{pH}$ values. Calculated $q_{\mathrm{eF}}$ at $\mathrm{pH}=8$ was 15.7 , and at $\mathrm{pH}=7.5$ the $q_{\mathrm{eF}}$ was $24.7 \mathrm{mg}$ of $\mathrm{As}(\mathrm{V})$ per $\mathrm{g}$ of Fe(III), which was in accordance with our results.

Similar to the precipitated iron(III) hydroxide, Bayoxide had a $K_{\mathrm{F}}$ of $0.47(\mathrm{mg} / \mathrm{g}) \cdot(\mathrm{L} / \mathrm{g})^{\mathrm{n}}$ in tap water, nearly $3.5-$ -fold higher than in demineralized water. When we used the calculated Freundlich constants and an $\gamma_{\mathrm{e}}(\mathrm{As}(\mathrm{V}))=5$ $\mu \mathrm{g} / \mathrm{L}$ in Eq. 1, $q_{\mathrm{eF}}$ was $0.42 \mathrm{mg}$ of $\mathrm{As}(\mathrm{V})$ per $\mathrm{g}$ of Bayoxide in tap water and $0.85 \mathrm{mg}$ of $\mathrm{As}(\mathrm{V})$ per $\mathrm{g}$ of Bayoxide in demineralized water. This large difference probably reflects the high adsorption intensity $(1 / n)$, which was 0.7535 in demineralised and 0.3639 in tap water. Our measurement of the adsorption capacity of Bayoxide is comparable to that of Westerhoff et al. (11), who reported a value of $0.5 \mathrm{mg}$ of $\mathrm{As}(\mathrm{V})$ per $\mathrm{g}$ of adsorbent. Lin et al. (7) observed a $K_{\mathrm{F}}$ of $16.7(\mathrm{mg} / \mathrm{g}) \cdot(\mathrm{L} / \mathrm{g})^{\mathrm{n}}$ for Bayoxide, but they used much higher As(V) concentrations than we did (5.1$20.8 \mathrm{mg}$ of $\mathrm{As}(\mathrm{V})$ per L).
In contrast to the other two adsorbents, Titansorb adsorbed more $\mathrm{As}(\mathrm{V})$ in tap than in demineralized water, where the Freundlich constant $K_{\mathrm{F}}$ was $0.05(\mathrm{mg} / \mathrm{g}) \cdot(\mathrm{L} / \mathrm{g})^{\mathrm{n}}$. Based on Eq. 1, $q_{\mathrm{eF}}$ was 0.14 and $0.11 \mathrm{mg}$ of $\mathrm{As}(\mathrm{V})$ per $\mathrm{g}$ of Titansorb in tap and demineralized water, respectively. Titansorb had the lowest $q_{\mathrm{eF}}$ of all three absorbents, which may be due to the $\mathrm{pH}$ values of model solutions ((8 \pm 0.1$)$ ). For example, Dutta et al. (19) reported that lower $\mathrm{pH}$ enhances the removal of $\mathrm{As}(\mathrm{V})$ from water by adsorption onto $\mathrm{TiO}_{2}$. Furthermore, Bang et al. (25), who worked with higher concentrations of competitive ions than we did, reported no obvious effect of silica and phosphorus on the adsorption of $\mathrm{As}(\mathrm{V})$ onto granular $\mathrm{TiO}_{2}$.

Table 2 reports the Langmuir constant $Q_{0}$, representing maximum monolayer coverage capacity and the Langmuir isotherm constant $K_{\mathrm{L}}$, representing the sorption capacity, of the three adsorbents (Fig. 2). Among the three,

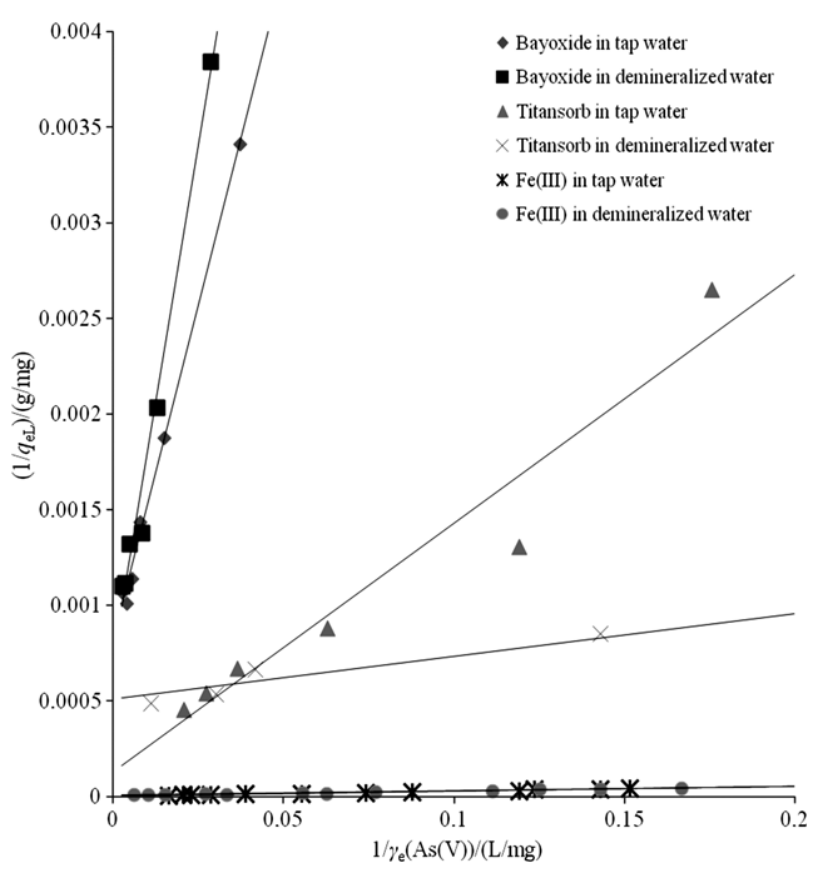

Fig. 2. Dependence of $\mathrm{As}(\mathrm{V})$ adsorbed at equilibrium $\left(q_{\mathrm{eL}}\right)$ on $\operatorname{As}(\mathrm{V})$ concentration $\left(\gamma_{\mathrm{e}}\right)$ in a solution, used to calculate Langmuir isotherm constants 
iron(III) hydroxide had the highest value of $Q_{0}(372.6$ $\mathrm{mg} / \mathrm{g})$ and Titansorb the lowest $(1.2 \mathrm{mg} / \mathrm{g})$ in tap water. The same trend was observed in demineralized water, with $Q_{0}$ of iron(III) hydroxide equal to $181.9 \mathrm{mg} / \mathrm{g}$, of Bayoxide to $8.0 \mathrm{mg} / \mathrm{g}$ and of Titansorb to $1.4 \mathrm{mg} / \mathrm{g}$. Iron(III) hydroxide had a $Q_{0}$ almost 2-fold higher in demineralized than in tap water, and Bayoxide had a $Q_{0}$ almost 5-fold higher in demineralized water. Titansorb, in contrast, had similar $Q_{0}$ in both types of water. However, our study focuses on the removal of low $\mathrm{As}(\mathrm{V})$ concentrations, considering drinking water treatment and consequently $Q_{0}$ values may not be representative of the adsorbent maximum adsorption capacity due to low initial arsenic concentrations employed.

Even though iron(III) hydroxide and Bayoxide E33 had substantially higher $Q_{0}$ values in demineralized water than in tap water, the fact that their calculated $K_{\mathrm{F}}$ values were much higher in demineralized water meant that the calculated capacity of adsorption $\left(q_{\mathrm{eL}}\right)$ was greater in tap water, as can be seen from the values of $q_{\mathrm{eL}}$ calculated from Eq. 2 at $\gamma_{\mathrm{e}}(\mathrm{As}(\mathrm{V}))=5 \mu \mathrm{g} / \mathrm{L}$. Titansorb had the smallest value of $q_{\mathrm{eL}}$ of all three adsorbents, indicating no significant influence of other ions on $\mathrm{As}(\mathrm{V})$ adsorption. Our Langmuir isotherm constants for $\mathrm{As}(\mathrm{V})$ removal were lower than those reported by Bang et al. (25) for granular $\mathrm{TiO}_{2}$, perhaps reflecting the fact that those authors used much higher As(V) concentrations (10-60 mg/L) in their adsorption tests. The same authors reported $K_{\mathrm{L}}=0.000172$ $\mathrm{L} / \mu \mathrm{g}, Q_{0}=40 \mathrm{mg} / \mathrm{g}$ and $q_{\mathrm{eL}}=1.7 \mathrm{mg} / \mathrm{g}$. Like us, they did not observe appreciable interference from other ions. During their column test experiments in which $\gamma_{0}=32 \mu \mathrm{g} / \mathrm{L}$, they observed $q_{\mathrm{eL}}$ of $0.11 \mathrm{mg} / \mathrm{g}$, which is similar to our results.

The separation factor $\left(R_{\mathrm{L}}\right)$ suggests the possibility of using Langmuir isotherm for adsorption of $\mathrm{As}(\mathrm{V})$, and it can indicate the adsorption as: unfavourable $\left(R_{\mathrm{L}}>1\right)$, linear $\left(R_{\mathrm{L}}=1\right)$, favourable $\left(0<R_{\mathrm{L}}<1\right)$ and irreversible $\left(R_{\mathrm{L}}=0\right)(20,21)$. Eq. 3 was used to calculate $R_{\mathrm{L}}$ for all three adsorbents: using $K_{\mathrm{L}}$ and $\gamma_{0}=100 \mu \mathrm{g} / \mathrm{L}$ gave values from 0.04 to 0.61 (Table 2). These values indicate favourable adsorption $\left(0<R_{\mathrm{L}}<1\right)$ by all three adsorbents.

Although the three adsorbents differed in adsorption capacity, $K_{\mathrm{F}}$ and $Q_{0}$ in tap and demineralized water (Table 2 ), they had similar values of $q_{\mathrm{eF}}$ and $q_{\mathrm{eL}}$ calculated from Eqs. 1 and 2. In addition, both isotherms gave high coefficients of determination $\left(\mathrm{R}^{2}\right)$. Higher coefficients were obtained using the Langmuir model, indicating that adsorption on all three adsorbents may be more accurately described by formation of an $\mathrm{As}(\mathrm{V})$ monolayer on the adsorbent surface.

Several studies have shown that higher water $\mathrm{pH}$ diminishes adsorption capacity, mostly due to changes in the charge of arsenate species, which then need two active sites on the adsorbent. Also, increase of $\mathrm{pH}$ value above the isoelectric point (IEP) of the adsorbent results in more negative charge of adsorbent surface $(26,27)$, which can diminish adsorption capacity. Bayoxide and freshly precipitated iron(III) hydroxide usually have IEP ranging between 7 and 7.5 (23) and that of $\mathrm{TiO}_{2}$ is lower, which could explain lower adsorption capacity of Titansorb in our study since we conducted experiment at higher $\mathrm{pH}$ values. Furthermore, $\mathrm{As}(\mathrm{V})$ adsorption is also influenced by the competitive ions present in the water, mostly by $\mathrm{OH}^{-}$,
$\mathrm{PO}_{4}{ }^{3-}, \mathrm{SO}_{4}{ }^{2-}$ and $\mathrm{NO}_{3}{ }^{-}(4,7,28)$. Tap water used in our experiments did not have high concentrations of the mentioned ions, but it can be seen from the obtained results that some influence on the adsorption capacity was present, mostly on iron(III) hydroxide and Bayoxide, and less on Titansorb.

\section{Adsorption column tests}

Column tests were conducted to measure the adsorption of $\mathrm{As}(\mathrm{V})$ by Bayoxide E33 and Titansorb from spiked tap water containing $100 \mu \mathrm{g}$ of $\mathrm{As}(\mathrm{V})$ per L (Fig. 3). Titansorb had a breakthrough point of $10 \mu \mathrm{g}$ of $\mathrm{As}(\mathrm{V})$ per $\mathrm{L}$ in the effluent after 1077 bed volumes, while Bayoxide could be used to treat 1436 bed volumes before the $\mathrm{As}(\mathrm{V})$ concentration in the effluent reached $10 \mu \mathrm{g} / \mathrm{L}$. Also, Bayoxide had adsorption capacity $(q)$ of $0.24 \mu \mathrm{g}$ of $\mathrm{As}(\mathrm{V})$ per $\mathrm{g}$, and Titansorb of $0.17 \mu \mathrm{g}$ of $\mathrm{As}(\mathrm{V})$ per $\mathrm{g}$, before achieving mass concentration of $\mathrm{As}(\mathrm{V})$ of $10 \mu \mathrm{g} / \mathrm{L}$ in treated water. Comparing $q$ values of the column test with calculated $q_{\mathrm{eF}}$ and $q_{\mathrm{eL}}$ values from Table $2, q_{\mathrm{e}}$ of Bayoxide was higher in the batch tests, indicating that Bayoxide should adsorb more $\mathrm{As}(\mathrm{V})$ from water in column test. This difference may be influenced by an EBCT in a column test, which was $12 \mathrm{~min}$. Similar influence of EBCT on the adsorption capacity of adsorbents was observed in the work of Tresintsi et al. (18). On the other hand, Titansorb in our experiment showed similar $q, q_{\mathrm{eL}}$ and $q_{\mathrm{eF}}$ values, which suggests that the employed EBCT did not influence its adsorption capacity.

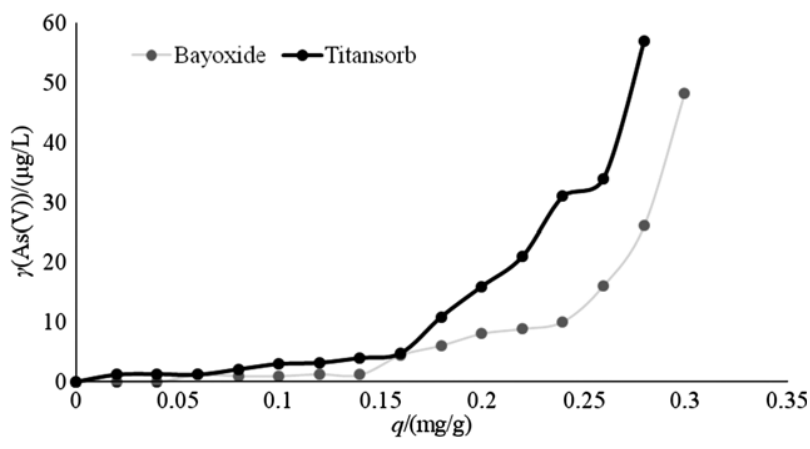

Fig. 3. Adsorption capacity $(q$, in $\mathrm{mg}$ of $\mathrm{As}(\mathrm{V})$ per $\mathrm{g}$ of adsorbent) test used for $\mathrm{As}(\mathrm{V})$ removal from tap water

\section{Conclusions}

Among the three adsorbents in this study, precipitated iron(III) hydroxide had the highest capacity for As(V) adsorption from both tap and demineralized water. Bayoxide had higher adsorption capacity than Titansorb in both the batch and column tests.

Other ions did not appear to appreciably influence $\mathrm{As}(\mathrm{V})$ adsorption by any of the three adsorbents tested here. Nevertheless, iron(III) hydroxide and Bayoxide demonstrated higher adsorption capacities in demineralized water than in tap water, with Bayoxide showing the greatest capacity difference between the types of water. Titansorb exhibited slightly better calculated adsorption capacity $q_{\mathrm{eL}}$ and $q_{\mathrm{eF}}$ in tap water than in demineralized wa- 
ter. All three adsorbents showed good adsorption, as values of separation factor $R_{\mathrm{L}}$ from Langmuir isotherms ranged between 0.04 and 0.61 .

Both Freundlich and Langmuir isotherms fit the experimental data with high coefficients of determination $(>0.9012)$ for all adsorbents, indicating that both models may be useful for representing $\mathrm{As}(\mathrm{V})$ adsorption. Nevertheless, the Langmuir model showed somewhat better results, which may mean that it represents more accurately $\mathrm{As}(\mathrm{V})$ adsorption on these three adsorbents.

\section{References}

1. Guidelines for drinking-water quality: First addendum to 3rd edition, vol. 1. Recommendations. Geneva, Switzerland: WHO Press, World Health Organization (WHO); 2006.

2. Smith $\mathrm{AH}$, Smith $\mathrm{MMH}$. Arsenic drinking water regulations in developing countries with extensive exposure. Toxicology. 2004;198:39-44.

http://dx.doi.org/10.1016/j.tox.2004.02.024

3. Goldberg S, Johnston CT. Mechanisms of arsenic adsorption on amorphous oxides evaluated using macroscopic measurements, vibrational spectroscopy, and surface complexation modeling. J Colloid Interf Sci. 2001;234:204-16. http://dx.doi.org/10.1006/jcis.2000.7295

4. Mohan D, Pittman Jr C. Arsenic removal from water/wastewater using adsorbents - a critical review. J Hazard Mater. 2007;142:1-53. http://dx.doi.org/10.1016/j.jhazmat.2007.01.006

5. Domenico PA, Schwartz FW. Physical and chemical hydrogeology. New York, NY, USA: John Wiley \& Sons; 1998.

6. Shih MC. An overview of arsenic removal by pressure-driven membrane processes. Desalination. 2005;172:85-97. http://dx.doi.org/10.1016/j.desal.2004.07.031

7. Lin TF, Liu CC, Hsieh WH. Adsorption kinetics and equilibrium of arsenic onto an iron-based adsorbent and an ion exchange resin. Water Sci Technol. 2006;6:201-7.

8. Shevade S, Ford RG. Use of synthetic zeolites for arsenate removal from pollutant water. Water Res. 2004;38:3197-204. http://dx.doi.org/10.1016/j.watres.2004.04.026

9. Payne KB, Abdel-Fattah TM. Adsorption of arsenate and arsenite by iron-treated activated carbon and zeolites: effects of $\mathrm{pH}$, temperature, and ionic strength. J Environ Sci Health A. $2005 ; 40: 723-49$. http://dx.doi.org/10.1081/ESE-200048254

10. Vithanage $M$, Chandrajith R, Bandara A, Weerasooriya R. Mechanistic modeling of arsenic retention on natural red earth in simulated environmental systems. J Colloid Interf Sci. 2006;294:265-72. http://dx.doi.org/10.1016/j.jcis.2005.07.026

11. Westerhoff P, De Haan M, Martindale A, Badruzzaman M. Arsenic adsorptive media technology selection strategies. Water Qual Res J Can. 2006;41:171-84.

12. Pattanayak J, Mondal K, Mathew S, Lalvani SB. A parametric evaluation of the removal of $\mathrm{As}(\mathrm{V})$ and $\mathrm{As}(\mathrm{III})$ by carbon-based adsorbents. Carbon. 2000;38:589-96. http://dx.doi.org/10.1016/S0008-6223(99)00144-X

13. Uwamariya V, Petrusevski B, Lens PNL, Amy G. Effect of calcium on adsorptive removal of $\mathrm{As}(\mathrm{III})$ and $\mathrm{As}(\mathrm{V})$ by iron oxide-based adsorbents. Environ Technol. 2014;35:3153-64. http://dx.doi.org/10.1080/09593330.2014.934739

14. Driehaus W. Arsenic removal - experience with the GEH (R) process in Germany. Water Sci Technol. 2002;2:275-80.

15. Pena ME, Korfiatis GP, Patel M, Lippincott L, Meng X. Adsorption of $\mathrm{As}(\mathrm{V})$ and $\mathrm{As}(\mathrm{III})$ by nanocrystalline titanium dioxide. Water Res. 2005;39:2327-37. http://dx.doi.org/10.1016/j.watres.2005.04.006

16. Edwards M. Chemistry of arsenic removal during coagulation and Fe-Mn oxidation. J Am Water Works Assoc. 1994; 86:64-78.

17. Jekel M, Amy GL. Arsenic removal during drinking water treatment. In: Newcombe G, Dixon D, editors. Interface science and technology, vol. 10. Philadephia, PA, USA: Elsevier, B.V.; 2006. pp. 193-206.

http://dx.doi.org/10.1016/S1573-4285(06)80080-3

18. Tresintsi S, Simeonidis K, Zouboulis A, Mitrakas M. Comparative study of $\mathrm{As}(\mathrm{V})$ removal by ferric coagulation and oxy-hydroxides adsorption: laboratory and full-scale case studies. Desalin Water Treat. 2013;51:2872-80. http://dx.doi.org/10.1080/19443994.2012.748011

19. Dutta PK, Ray AK, Sharma VK, Millero FJ. Adsorption of arsenate and arsenite on titanium dioxide suspensions. J Colloid Interf Sci. 2004;278:270-5. http://dx.doi.org/10.1016/j.jcis.2004.06.015

20. Foo KY, Hameed BH. Insights into the modeling of adsorption isotherm systems. Chem Eng J. 2010;156:2-10. http://dx.doi.org/10.1016/j.cej.2009.09.013

21. Weber TW, Chakravorti RK. Pore and solid diffusion models for fixed-bed adsorbers. AIChE J. 1974;20:228-38. http://dx.doi.org/10.1002/aic.690200204

22. Clesceri LS, Greenberg AE, Eaton AD, editors. Standard methods for the examination of water and wastewater. Washington, DC, USA: American Public Health Association (APHA); 1998.

23. Cornell RM, Schwertmann U. The iron oxides: structure, properties, reactions, occurrences and uses. Weinheim, Germany: Wiley-VCH Verlag GmbH \& Co. KGaA; 2003.

24. Mitrakas MG, Panteliadis PC, Keramidas VZ, Tzimou-Tsitouridou RD, Sikalidis CA. Predicting $\mathrm{Fe}^{3+}$ dose for $\mathrm{As}(\mathrm{V})$ removal at $\mathrm{pHs}$ and temperatures commonly encountered in natural waters. Chem Eng J. 2009;155:716-21. http://dx.doi.org/10.1016/j.cej.2009.09.011

25. Bang S, Patel M, Lippincott L, Meng X. Removal of arsenic from groundwater by granular titanium dioxide adsorbent. Chemosphere. 2005;60:389-97. http://dx.doi.org/10.1016/j.chemosphere.2004.12.008

26. Tresintsi S, Simeonidis K, Vourlias G, Stavropoulos G, Mitrakas M. Kilogram-scale synthesis of iron oxy-hydroxides with improved arsenic removal capacity: study of Fe(II) oxidation-precipitation parameters. Water Res. 2012;46:525567.

http://dx.doi.org/10.1016/j.watres.2012.06.049

27. Wu S, Hu W, Luo X, Deng F, Yu K, Luo S, et al. Direct removal of aqueous $\mathrm{As}(\mathrm{III})$ and $\mathrm{As}(\mathrm{V})$ by amorphous titanium dioxide nanotube arrays. Environ Technol. 2013;34:2285-90. http://dx.doi.org/10.1080/09593330.2013.765923

28. Guan X, Du J, Meng X, Sun Y, Sun B, Hu Q. Application of titanium dioxide in arsenic removal from water: a review. J Hazard Mater. 2012;215-216:1-16. http://dx.doi.org/10.1016/j.jhazmat.2012.02.069 